\title{
Some opinions about the groundwater origin formation of middle - upper Pleistocene aquifer in Ca Mau peninsula
}

- Dao Hong Hai

- Nguyen Viet Ky

Geology and Petroleum Engineering, University of Technology, VNU-HCM

- Bui Tran Vuong

Division for Water Resources Planning and Investigation for the South of Viet Nam

- Nguyen Dinh Tu

Viet Nam National University - Ho Chi Minh City

(Manuscript Received on August 04 ${ }^{\text {th }}, 2014$; Manuscript Revised November 11 $1^{\text {th }}, 2014$ )

\begin{abstract}
:
In Ca Mau peninsula region, groundwater resource is the main source of water supply for agriculture, industry, domestic uses. In this paper, the authors study groundwater origin in middle upper pleistocene (qp2-3) aquifer in $\mathrm{Ca} \mathrm{Mau}$ peninsula and give some opinions about the groundwater origin formation for planning and managing reasonable, safe, and sustainable. There are many studies about groundwater origin in the Mekong delta plains and these studies showed different results. Up till now, there is not a consensus on an exact origin of groundwater in Mekong delta plains, especially in Ca Mau peninsula. Therefore, the authors use the Xulin approach to determine groundwater origin based on the concentration of ions $\mathrm{Na}+, \mathrm{Cl}-$, SO42-, Mg2t. Then we use Piper diagram, Gibbs plot, Mercado plot, and hydro-geochemical section plot

to explain the origin of groundwater in Ca Mau peninsula region. The results show that there are 4 types of groundwater origin in the studied region: magnesium - chloride, marine origin; calcium chloride, deep metamorphic environment; sodium - sulfate, the continental leaching origin; bicacbonnat-sodium, continental environment. The groundwater origins relate to the marine transgression and regression process, or weathering, leaching, and freshwash processes. The groundwater origin formation do not have participation of rainfall water and river water, which are two important components contribute to the groundwater recharge formation. Therefore, researching groundwater recharge of the qp2-3 aquifer in the Ca Mau peninsula is according to other aspects.

Keywords: Ca Mau peninsula; Hydrogeochemical groundwater; Groundwater origin.

\section{INTRODUCTION}

Ca Mau Peninsula (CMP) is one of five large regions of the Mekong River Delta (MRD), which includes Can Tho, Hau Giang, Soc Trang, Bac Lieu, Ca Mau, and a part of Kien Giang provinces. CMP plays an important role in economic and social development in Mekong delta region and Viet Nam. Most of this area

terrain rise from 0.2 to $1.0 \mathrm{~m}$ and the main slope is northeast - southwest. The alluvial settlement from Hau river has formed natural level a high terrain along Hau river, and low terrain toward Cai Be, Cai Lon rivers, and west Sea. Groundwater is one of the main water resources supplying for people's lives and economic activities (agriculture, industry, aquaculture, ...) in the studied area. In recent years, economic development
\end{abstract}


and population explosion in the region make water resource for human demands increasingly scarce. Therefore, studying the quality and quantity of groundwater resources in CMP serving the planning and management of groundwater resources to ensure sustainable development is an urgent issue today. Several previous studies have evaluated the quality and quantity of the aquifers in the Mekong Delta (Bui Tran Vuong et al., 2013), and the planning schemes of utilization and protection of groundwater resources has been carried out in provinces of Soc Trang, Can Tho, Hau Giang, Bac Lieu by the experts in the Division for Water Resources Planning and Investigation for the South of Viet Nam. These researches have identified potential reserves of groundwater resources in the region and have built up a map of fresh - salt distribution of the aquifers in Mekong Delta. However, the Mekong delta has complex geological conditions (Bui Tran Vuong et al., 2013). Therefore, there is a need to determine the origin of the groundwater formation to ensure planning and sustainable exploitation of the area. In previous studies, scientists came up some of different perspectives: the groundwater resources of Mekong delta are originated from Cambodia, and Southeast of Viet Nam; the groundwater is originated fossil - water; and the groundwater is originated from rainfall and surface water (especially from Tien and Hau rivers). In this study, the authors analyze origins of groundwater formation in middle - upper pleistocence aquifer (this aquifer now was exploited exceeding in the region), and present some opinions about those processes to help plan, manage and use groundwater resource in $\mathrm{Ca} \mathrm{Mau}$ peninsula.

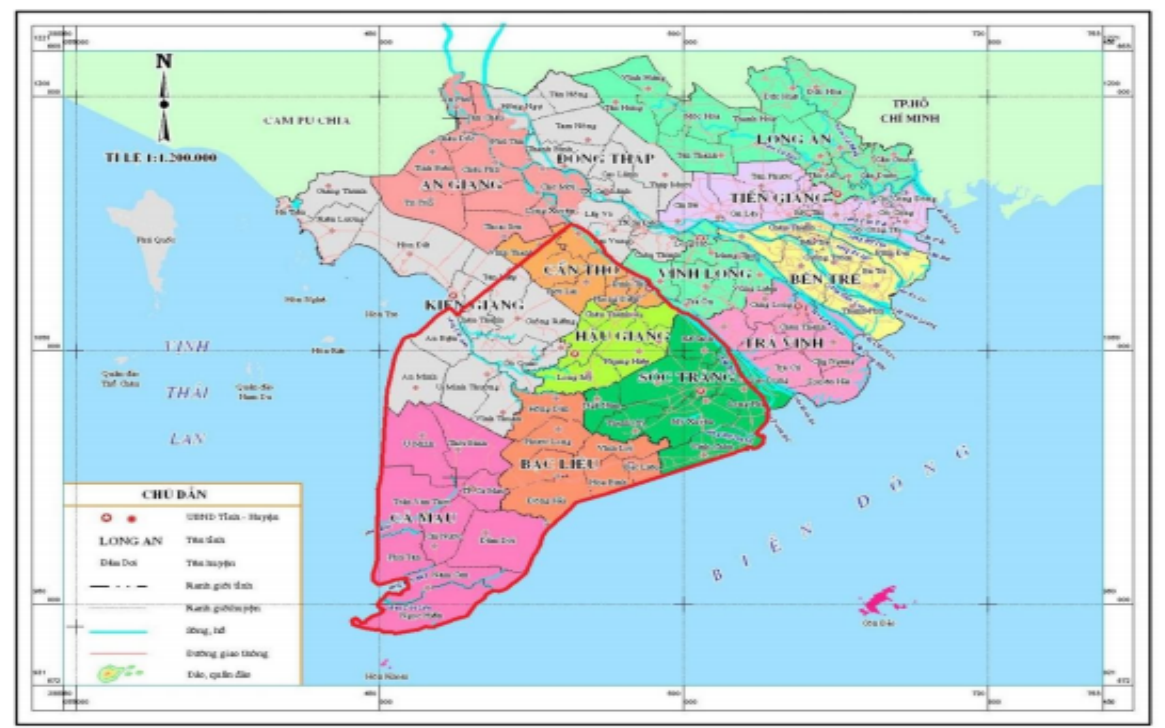

Figure 1. Administrative map of Ca Mau Peninsula

\section{HYDROGEOLOGYCAL CHARACTERISTICS}

Results of hydrogeological studies show that in $\mathrm{Ca}$ Mau peninsula region there are 8 main aquifers: the holocene (qh), the uper pleistocene $\left(\mathrm{qp}^{3}\right)$, the middle uper pleistocene $\left(\mathrm{qp}^{2-3}\right)$, the lower pleistocene $\left(\mathrm{qp}^{1}\right)$, the middle pliocene $\left(n_{2}^{2}\right)$, the lower pliocene $\left(n_{2}^{1}\right)$, the upper miocene $\left(\mathrm{n}_{1}^{3}\right)$ and the middle - upper miocene $\left(\mathrm{n}_{1}^{2-3}\right)$. However, middle - upper miocene layer $\left(\mathrm{n}_{1}{ }^{2-3}\right)$ locates very deep and have not been researched yet. Therefore, the CMP has 7 main aquifers. The middle upper pleistocene aquifer $\left(\mathrm{qp}^{2-3}\right)$ is widely distributed throughout the studied region and has area $16.940 \mathrm{~km}^{2}$.
The aquifer created by middle - upper pleistocene sediments has river origin $\left(\mathrm{aQ}_{1}{ }^{2-3}\right)$ and river - marine origin $\left(\mathrm{amQ}_{1}{ }^{2-3}\right)$ : The main lithological medium sand with gravel $\left(\mathrm{aQ}_{1}{ }^{2-3}\right)$ alternating clamp the thin layer of clayey silt with sandy $\left(\mathrm{amQ}_{1}{ }^{2-3}\right)$. The $\mathrm{qp}^{2-3}$ aquifer is not exposed on surface which is directly covered up by impermeably geological formations middle - upper pleistocene marine origin $\left(\mathrm{mQ}^{2-3}\right)$ which is not continuous due to some of location is eroded by rivers $\left(\mathrm{Q}_{1}{ }^{3}\right)$. As the result, there is water exchange between the $\mathrm{qp}^{2-3}$ and $\mathrm{qp}^{3}$ aquifers. According to the results of analysis collected from 268 boreholes, the top depth of aquifer ranges from $9.7 \mathrm{~m}$ to $132.5 \mathrm{~m}, 56.0 \mathrm{~m}$ on average;

\section{Trang6}


the bottom of aquifer ranges from $24.5 \mathrm{~m}$ to $179.0 \mathrm{~m}$, $63.6 \mathrm{~m}$ on average; The minimum thickness is $2.00 \mathrm{~m}$, the maximum thickness is $100.3 \mathrm{~m}, 41.5 \mathrm{~m}$ on average (Dao Hong Hai, 2014). Hydrogeological cross sections (Figure 2) shows that the bottom of $\mathrm{qp}^{2-3}$ aquifer tend to sink deep at the Soc Trang Province and southeast study area, and rise up at northeast and southwest study area. Similarly, cross sections in figure 2 , show that the bottom of aquifer lower from northwest to southeast and expand in some areas such as Can Tho City, and Bac Lieu city.

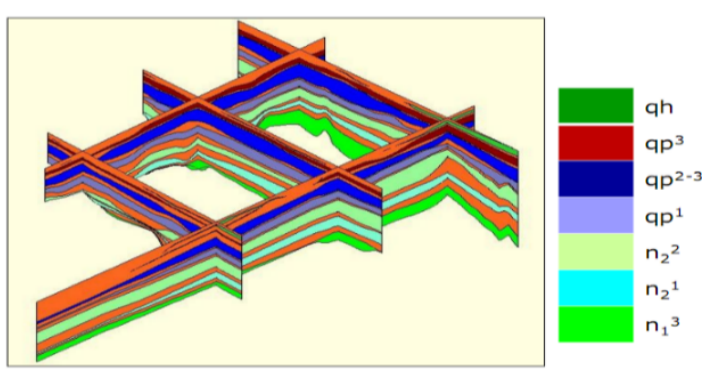

Figure 2. The 3D hydrogeology cross sections of the aquifers in $\mathrm{Ca}$ Mau Peninsula

\section{USED DATA AND MENTHODS}

The study is based on 90 analysis samples in the $\mathrm{qp}^{2-3}$ aquifers, which were taken from national monitoring stations, the hydro-geological boreholes, the groundwater extraction projects, the whole of them belongs to the project "Assessment the impact of climate change on Mekong delta groundwater resources, proposed solutions" (Bui Tran Vuong et al., 2013). In this study the authors focus on analyzing main cation concentrations.$\left(\mathrm{Na}^{+}, \mathrm{K}^{+}, \mathrm{Ca}^{2+}, \mathrm{Mg}^{2+}\right)$, and anions $\left(\mathrm{HCO}_{3}{ }^{-}, \mathrm{Cl}^{-}, \mathrm{SO}_{4}{ }^{2-}\right)$, and the total dissolved solids (TDS) in groundwater samples. All groundwater samples were taken and experimented under Vietnamese standards, set by the Division for Water Resources Planning and Investigation for the South of Viet Nam.

Research literature Ca Mau peninsula is a new area of researches on groundwater resources supplied for human activities so is limited. Therefore, in this study the authors inherit results of distribution fresh - salt boundary from the project " assessment the impact of climate change on Mekong delta groundwater resources, proposed solutions " (Vuong Bui Tran et al., 2013 ). using statistical analysis methods to determine the background values of major anions and cations in groundwater and TDS, and determine anomalous values of the major ions in groundwater (by $3 \sigma$ errors eliminate method) to confirm the salinity distribution maps. Based on the chemically reactive of ions, we establish the ratio of $\mathrm{rNa}^{+} / \mathrm{rCl}^{-},\left(\mathrm{rCl}^{-}-\mathrm{rNa}^{+}\right) / \mathrm{rSO}_{4}{ }^{2-} ;\left(\mathrm{rCl}^{-}\right.$ - $\left.\mathrm{rNa}^{+}\right) / \mathrm{rMg}^{2+}$ and use the Xulin classification method to determine originated formation of groundwater in the $\mathrm{qp}^{2-3}$ aquifer, then use the hydro-geochemical values in the area describes on the Piper diagram, Gibbs, and Mercado plot. to determine causes of the formation of these originated types.

\section{RESULTS AND DISCUSSION}

We have identified background values of major ions in groundwater based on statistical analysis of 90 groundwater samples and error elimination (Table 1). According to above parameters, except $\mathrm{pH}$ and anion $\mathrm{HCO}_{3}{ }^{-}$is normal, other ions are anomalous:

Cation $\mathrm{Na}^{+}$has 6 anomalous samples) and values range from $520 \mathrm{mg} / \mathrm{l}$ to $7,423 \mathrm{mg} / \mathrm{l}$. the focus points are in the center of the study area (3 points) and in the Eastern - northern of Soc Trang province (3 points). Cation $\mathrm{Ca}^{2+}$ has 6 anomalous samples and values range from $220 \mathrm{mg} / \mathrm{l}$ to $1,300 \mathrm{mg} / \mathrm{l}$ similarly ion $\mathrm{Na}^{+}$has 3 points distributed in Hau Giang province, and 3 points in Soc Trang province. Ion $\mathrm{Mg}^{2+}$ has 8 anomalous samples and values range from $280 \mathrm{mg} / 1$ to $1,060 \mathrm{mg} / \mathrm{l}$, mainly focused in Can Tho province and 1 point in Bac Lieu province. Anion $\mathrm{Cl}^{-}$has 22 anomalous samples and values range from $216 \mathrm{mg} / \mathrm{l}$ to $7,872 \mathrm{mg} / \mathrm{l}$ centered in Soc Trang and Hau Giang city stretching up and along from Hau Giang province to Rach Gia city. Anion $\mathrm{SO}_{4}{ }^{2-}$ has 10 anomalous samples and values range from $507 \mathrm{mg} / \mathrm{l}$ to $3,190 \mathrm{mg} / \mathrm{l}$. These points spread along the east NW - SE consists of Soc Trang, Hau Giang, and Kien Giang provinces. Using Xulin method, we setup a ratio of the ions percentage (meq/l) of $\mathrm{rNa}^{+} / \mathrm{rCl}^{-}$. Results show that 50 out of 90 groundwater samples have $\mathrm{rNa}^{+} / \mathrm{rCl}^{-}>1 . \mathrm{Na}^{+}$excess proves that these samples is originated from the continent, 26 samples have $\left(\mathrm{rNa}^{+}\right.$ - $\left.\mathrm{rCl}^{-}\right) / \mathrm{rSO}_{4}{ }^{2-}$ ratio $>1$, this mean these samples are of sodium bicarbonates continental environment distributed throughout the provinces in the region (Figure 3). 
24 groundwater samples have $\left(\mathrm{rNa}^{+}-\mathrm{rCl}^{-}\right) / \mathrm{rSO}_{4}{ }^{2-}$ $<1$ so the groundwater samples are of sodium Sulfatecontinental leaching origin concentrated in Southern Ca Mau peninsula, and entire Soc Trang province, and some distributed in the southern boundary of Hau Giang, Can Tho, Bac Lieu provinces (Figure 4).

The rest 40 samples have $\mathrm{rNa}^{+} / \mathrm{rCl}^{-}$ratio $<1 \mathrm{Cl}^{-}$ excess proves that groundwater samples are originated from seawater, 29 samples have $\left(\mathrm{rCl}^{-}-\mathrm{rNa}^{+}\right) / \mathrm{rMg}^{2+}$ ratio $<1$, which concentrate in east and north-east along Hau river and Tran De estuary, some samples scatter in Hau Giang and Can Tho provinces. These groundwater samples are of magnesium - chloride, marine origin (Figure 5).

11 samples have $\left(\mathrm{rCl}^{-}-\mathrm{rNa}^{+}\right) / \mathrm{rMg}^{2+}$ ratio $>1$ which spread linearly from east to west studied areas (Tran De estuary to Cai San canal) and belong to chlorideCalcium deep metamorphic environment (Figure 6).

In addition, to determine the distribution of freshsalt boundary of groundwater of the $\mathrm{qp}^{2-3}$ aquifer in CMP the authors based on geophysical cuments and chemical analysis results of 90 oundwater samples, which are described in Figure 7. In Figure 7 shows the distribution of the total dissolved solid (TDS), with:

- TDS $<1 \mathrm{~g} / \mathrm{l}$ is the fresh groundwater (blue); and

- TDS $>1 \mathrm{~g} / \mathrm{l}$ is salt groundwater (red).

Clasification results of the Xulin method about groundwater is shown in Figure 8. Overlaping 2 map (fresh-salt boundary map and groundwater classification map of Xulin method) show that the groundwater samples which have origin bicacbonnatsodium, continental environment are distributed on the saltwater background even themselves has TDS $>1 \mathrm{~g} / \mathrm{l}$ and also groundwater samples which have origin $\mathrm{Mg}-\mathrm{Cl}$ marine origin, $\mathrm{Cl}-\mathrm{Ca}$ deep metamorphic origin are distributed in areas with TDS $<1 \mathrm{~g} / \mathrm{l}$. The authors have used Mercado plot, Gibbs plot, Piper diagram, and hydro-geochemical plot to explain the formation of these groundwater origins.

Results of Mercado analysis (Figure 9) show that the upper branches of plot which have groundwater samples tend to shift toward the upper left corner proving in the groundwater formation had occurred freshwash process, and the centre of plot there are many groundwater samples show that in the groundwater formation had occurred the mixture of groundwater types which there are different origins.

The results of the analysis according to Gibbs plot (Figure 10), showing the composition of the groundwater samples $\mathrm{Na}(\mathrm{Na}+\mathrm{Ca}), \mathrm{Cl}\left(\mathrm{Cl}+\mathrm{HCO}_{3}\right)$ moved to the upper left of the plot have groved evaporation, weathered process in the aquifer, and the plot also shows that there is no involvement of rainwater and river water in recharge process, the upper right corner appears few groundwater samples proved sea water also intrusive, but very little. The results of analysis by Piper diagram (Figure 11), salinization process has occurred in the past and nowaday is positive influence, and the process of fresh-wash forming and developing in the region. According to the hydrogeological cycle in CMP in Figure 12 shown that there are 2 types of hydro-geochemical sections in the provinces of Ca Mau and Soc Trang, where there are anomalous about chemical composition of groundwater in the qp2-3, first type is a reversible cycle, the second type is a mixture cycle, and during to forming the pleistocene sediments are transition process from marine transgression process to marine regression process. therefore, the groundwater has many origin types, and is most evident in Soc Trang Province.

Table 1. Background Values of main ions of the qp2-3 aquifer in CMP

\begin{tabular}{|cccccc|}
\hline Parameters & Maximum & Minimum & Average & Standard deviation & Background values \\
\hline $\mathrm{pH}$ & 8.89 & 6.26 & 7.71 & 0.53 & $6.26-8.89$ \\
$\mathrm{TDS}(\mathrm{mg} / \mathrm{l})$ & 24.75 & 0.30 & 0.86 & 0.44 & $0.30-2.51$ \\
$\mathrm{Na}^{+}(\mathrm{mg} / \mathrm{l})$ & $7,423.00$ & 9.21 & 79.86 & 60.40 & $9.21-259.11$ \\
$\mathrm{~K}^{+}(\mathrm{mg} / \mathrm{l})$ & 119.98 & 2.86 & 11.88 & 6.78 & $2.86-32.20$ \\
$\mathrm{Ca}^{2+}(\mathrm{mg} / \mathrm{l})$ & $1.300,01$ & 8.02 & 70.29 & 45.58 & $8.02-200.00$ \\
$\mathrm{Mg}^{2+}(\mathrm{mg} / \mathrm{l})$ & $1,059.96$ & 7.90 & 76.38 & 56.37 & $7.90-219.99$ \\
$\mathrm{HCO}^{3-}(\mathrm{mg} / \mathrm{l})$ & 731.91 & 36.60 & 315.61 & 130.04 & $36.60-731.91$ \\
$\mathrm{Cl}^{-}(\mathrm{mg} / \mathrm{l})$ & $14,537.90$ & 0.70 & 65.75 & 42.40 & $0.70-187.04$ \\
$\mathrm{SO}_{4}^{2-}(\mathrm{mg} / \mathrm{l})$ & $3.191,09$ & 2,40 & 129,99 & 111,26 & $2.402,00-394.10$ \\
\hline
\end{tabular}

\section{Trang 8}




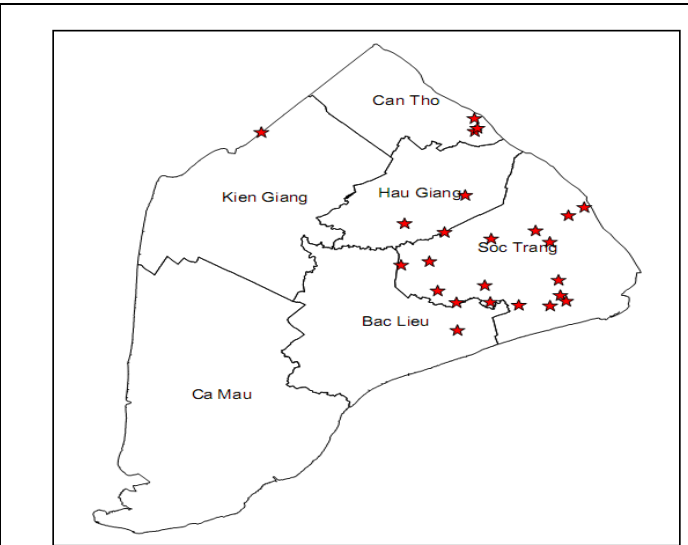

Figure 4. The distribution of origin groundwater sodium - sulfate, the continental leaching origin in the $\mathrm{qp}_{2-3}$ aquifer of $\mathrm{Ca}$ Mau peninsula

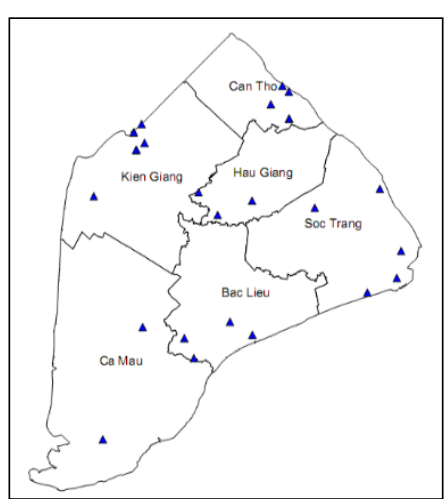

Figure 3. The distribution of groundwater origin bicacbonat-sodium, continental environment in the $\mathrm{qp}_{2-3}$ aquifer of $\mathrm{Ca} \mathrm{Mau}$ peninsula

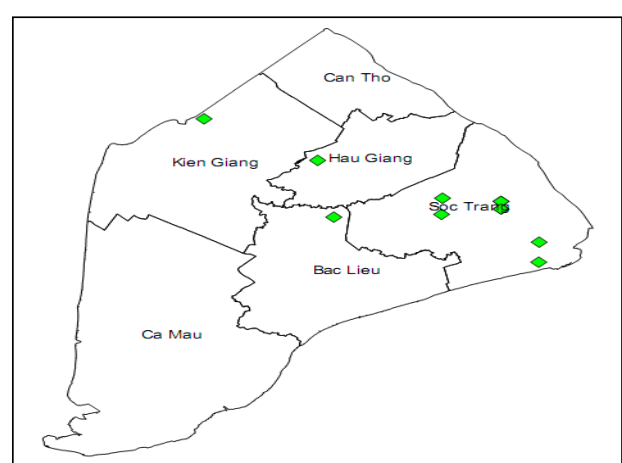

Figure 6. The distribution of groundwater origin calcium - chloride, deep metamorphic environment of the $\mathrm{qp}_{2-3}$ aquifer in Ca Mau peninsula

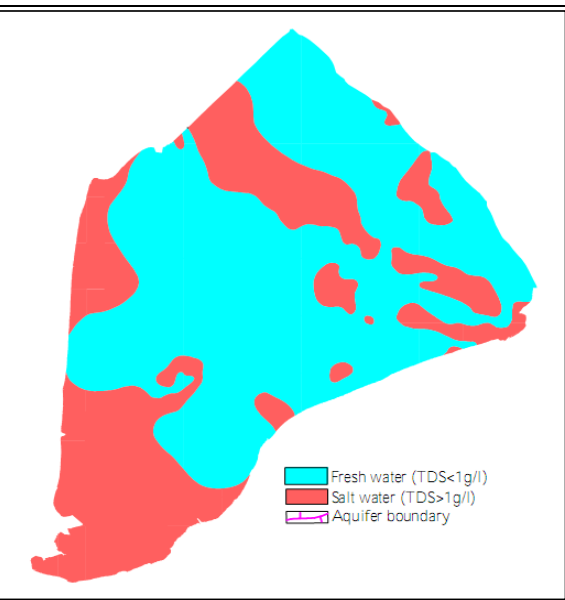

Figure 7. The distribution of fresh-salt boundary of the qp2-3 aquifer in Ca Mau peninsula

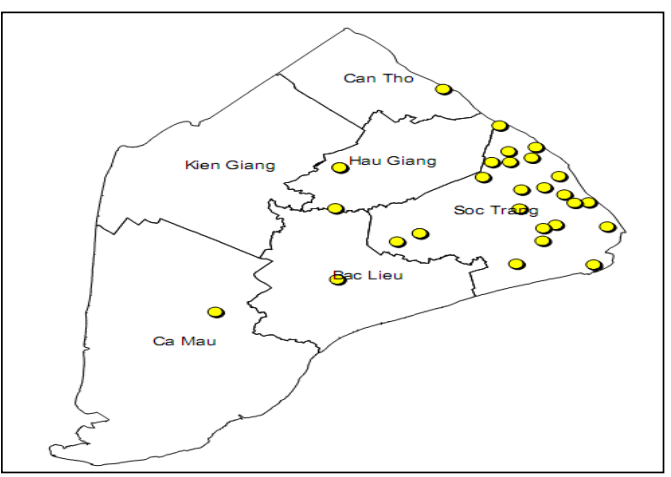

Figure 5. The distribution of origin groundwater magnesium - chloride marine origin in the $\mathrm{qp}_{2-3}$ aquifer of Ca Mau peninsula

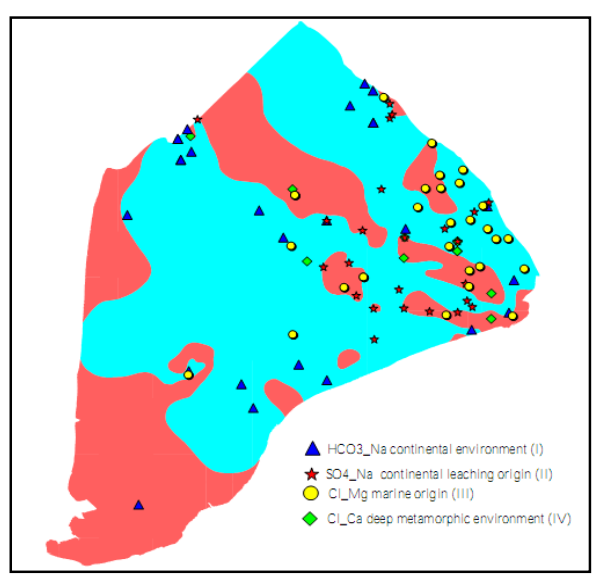

Figure 8. The groundwater clasification map of Xulin of the $\mathrm{qp}_{2-3}$ aquifer in Ca Mau peninsula 


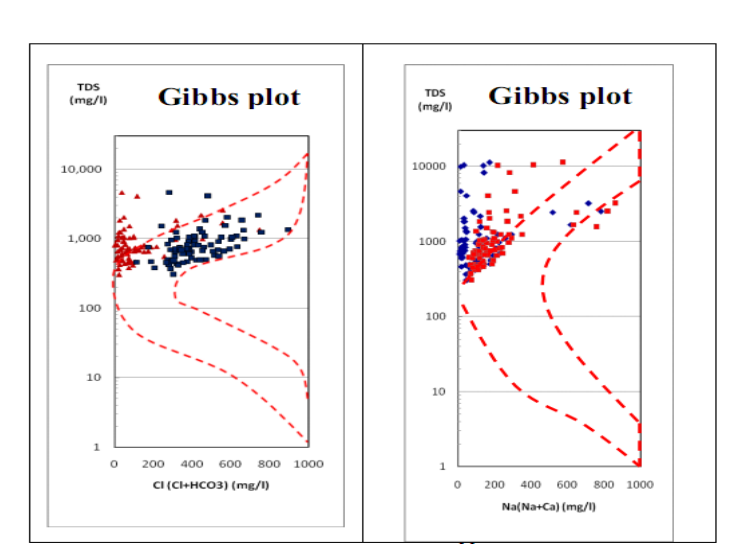

Figure 10. The Gibbs plot of groundwater in the $\mathrm{qp}^{2-3}$ aquifer of $\mathrm{Ca}$ Mau peninsula

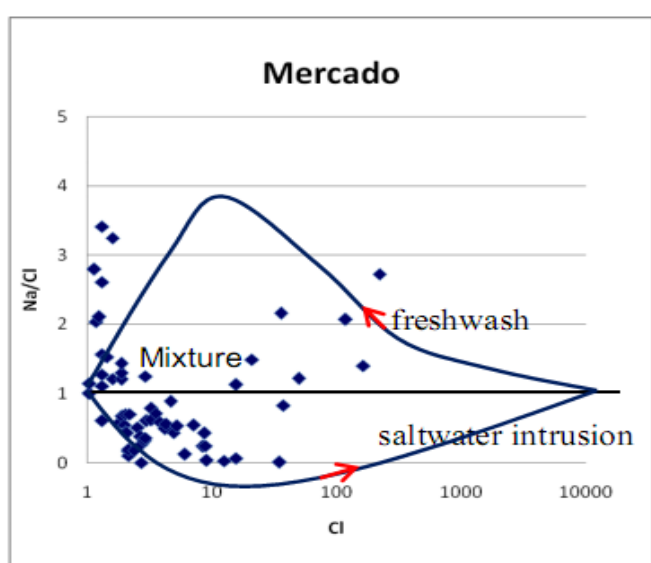

Figure 9. Mercado plot of groundwater in the $\mathrm{qp}_{2-3}$ aquifer of $\mathrm{Ca} \mathrm{Mau}$ peninsula

\section{CONCLUSION}

Based on classification results of Xulin showed 4 groundwater types in $\mathrm{qp}^{2-3}$ aquifer of Ca Mau peninsula, to combine analysis results follow Xulin with results of the Gibbs plot, Mercado plot, hydro-geochemical section, and Piper diagram could explain the types of groundwater origin formation in the area as follows: The marine transgression process creates groundwater origin is magnesium - chloride marine origin (29 samples), then go through the sedimentation process and tectonic movements have created groundwater origin is Calcium chloride deep metamorphic environment (11 samples), then undergo marine regression process, the freshwash process, the driftwood washing and solution process which have transported groundwater from elsewhere to form fossil water, that made groundwater has origin is sodium sulfate, the continental leaching origin (24 samples), and followed by development of evaporation and weathering processes create groundwater has origin sodium - bicarbonate continental environment (26 samples). To determine the exact time of these processes, we need to carry out research projects to analyze the absolute age of the groundwater (method of isotope hydrogeology) that will demonstrate more clearly the role of the processes and the time of groundwater formation in the qp2-3 aquifer of $\mathrm{Ca} \mathrm{Mau}$ peninsula.

ACKNOWLEDGMENT: The authors would like to thank the Division for Water Resources Planning and Investigation for the South of Viet Nam has allowed the authors use data from the project" assessment the impact of climate change on Mekong delta groundwater resources, proposed solutions "(Bui Tran Vuong et al, 2013) to implement this article.

\section{Trang 10}




\section{Một số nhận định về sự hình thành nguồn gốc nước dưới đất trong tầng Pleistocene giữa trên khu vực bán đảo Cà Mau}

- Đào Hồng Hải

- Nguyễn Việt Kỳ

Trường Đại học Bách Khoa, ĐHQG - HCM

- Bùi Trần Vượng

Liên đoàn Quy hoạch và điều tra tài nguyên nước miền Nam

- Nguyễn Đình Tứ

Đại học Quốc Gia thành phố Hồ Chí Minh

\section{TÓM TÁT:}

Khu vực bán đảo Cà Mau tài nguyên nước dưới đất là nguồn chính cung cấp nước trong nông nghiệp, công nghiệp, sinh hoạt và ăn uống của người dân. Trong bài báo này, nhóm tác giả tiến hành nghiên cứu nguồn gốc nước dưới đất trong tầng chứa nước Pleistocene giữa trên (qp2-3) vùng bán đảo Cà Mau và đưa ra một số nhận định về sự hình thành nguồn gốc nước dưới đất phục vu cho công tác quy hoạch và quản lý một cách hợp lý, an toàn, và bền vững. Trong những năm gần đây đã có nhiều nhà khoa học đề cập về nguồn gốc nước dưới đất khu vực đồng bằng sông Cửu Long, tuy nhiên đến thời điểm này vẫn chưa có nghiên cứu nào khẳng định một cách chính xác về nguồn gốc của nước dưới đất khu vực đồng bằng sông Cửu Long nói chung và bán đảo Cà Mau nói riêng. Vì vậy, nhóm tác giả đã nhìn nhận trên một khía cạnh khác, xác định sự hình thành nguồn gốc nước dưới đất theo Xulin, dựa vào nồng

Từ khóa: Bán đảo Cà Mau, Đặc điểm thủy địa hóa nước dưới đất, nguồn gốc nước dưới đất

\section{TÀI LIỆU THAM KHẢO}

[1]. Bùi Trần Vượng và nnk, Đánh giá chất lượng tài nguyên nước duới đất đồng bằng sông Cưu Long, Liên đoàn qui hoạch và điều tra tài nguyên nước miền Nam, 2013.

[2]. Bùi Trần Vượng, Sự hình thành thành phần hóa học nước duoói đất trong các đồng bằng ven biển độ của các ion $\mathrm{Na}+, \mathrm{Cl}$, SO42-, Mg2+. để xác định nguồn gốc của nước. đồng thời sử dụng các biểu đồ Gibbs, Piper, Mercado, mặt cắt thủy địa hóa để giải thích sự hình thành các nguồn gốc đó. Kết quả đã chỉ ra trong khu vực nghiên cứu có tồn tại 4 loại nguồn gốc : Clorua-magnhe nguồn gốc biển; Clorua-caxi môi trường biến chất sâu; Sunfat-natri nguồn gốc rửa lũa lục địa; Bicacbonnat-Natri môi trường đại lục. Các phương pháp phân tích cũng đã chỉ ra các quá trình hình thành các kiểu nguồn gốc nước dưới đất gồm quá trình biển tiến biển thoái, quá trình rửa trôi phong hóa, nhạt hóa và mặn hóa. Và kết quả phân tích chỉ ra nguồn hình thành thành phần hóa học nước dưới đất không có sự tham gia của nước mưa và nước sông, đây là 2 thành phần bổ cập quan trọng góp hình thành trữ lượng của nước dưới đất, vì vậy để nghiên cứu trữ lượng khai thác an toàn của tầng chứa nước qp2-3 cần tìm hiểu theo các khía cạnh khác.
Nam Trung Bộ, Tạp chí các khoa học về trái đất, 2008.

[3]. Nguyễn Kim Ngọc và nnk, Thủy địa hóa, NXB Giao thông vận tải, 2005.

[4]. Vũ Ngọc kỷ và nnk, Địa chất thủy văn đại cuoong, 1983 
[5]. Nguyễn Việt Kỳ và nnk, Hướng dẫn thực hành địa chất thủy văn, NXB ĐHQG TP.HCM, 2006

[6]. Daniela Ducci et al, Hydrogeochemical characterization of the main aquifer of the "Litorale Domizio-Agro Aversano NIPS" (Campania - southern Italy), Journal of Geochemical Exploration, 2013.
[7]. Thuy Nguyen Thanh et al, Hydrogeochemical characteristics of groundwater from the two main aquifers in the Red River Delta, Vietnam, Journal of Asian Earth Sciences, 2014

[8]. Tug ־anur Özen et al, Reservoir and hydrogeochemical characterizations of geothermal fields in Salihli, Turkey, Journal of Asian Earth Sciences, 2012.

\section{Trang D}

